Kościót Chrystusowy, red. T. Dzidek, Ł. Kamykowski, A. Napiórkowski,

Kraków 2019, s. 13-22 (Teologia Fundamentalna, 4)

DOI: http://dx.doi.org/10.15633/9788374388368.02

\title{
I. Pytanie o kościół
}

\author{
o. Andrzej Napiórkowski OSPPE
}

Objawienie judeo-chrześcijańskie swój szczyt i pełnię znalazło w osobie Jezusa, który jest Mesjaszem. Gdy chcemy Go odkryć, to zaraz na początku stwierdzamy, iż dotarcie do historycznego Jezusa z Nazaretu nie wyczerpuje całego bogactwa Jego osoby i dzieła. Przede wszystkim należy Go postrzegać jako Chrystusa. Pytamy zatem już nie tylko o rozumowe przesłanki, lecz o wiarę. Tego wyższego stopnia poznania swojej tożsamości Jezus oczekuje od swoich wyznawców. Pod Cezareą Filipową postawił pytanie apostołom: „A wy za kogo mnie uważacie?” (Mt 16, 15). To wspomagana rozumem wiara, jaką wyznaje św. Piotr, a wraz z nim Kościół wszystkich czasów, jest właściwym sposobem przeniknięcia do tego misterium: „Ty jesteś Mesjasz, Syn Boga żywego” (Mt 16, 16). Jezus, poruszony wyznaniem Piotra, stwierdza, iż nie objawiły mu tego „ciało i krew”, ale Ojciec niebieski. Wyrażenie „ciało i krew” oznaczają całego człowieka i naturalną drogę poznania. Aby zatem odpowiednio dotrzeć do osoby Jezusa Chrystusa i Jego zbawczego dzieła, nie można poprzestać na intelektualnej refleksji. Niezbędna jest, pochodząca od Ojca Niebieskiego, łaska Objawienia udzielana we wspólnocie wiary Kościoła ${ }^{1}$. Stąd pytanie o Jezusa Chrystusa, będącego samą istotą chrześcijaństwa, staje się jednocześnie pytaniem o Kościół.

Odpowiedzi na te pytania próbuje udzielić teologia fundamentalna w nauce o Kościele. Eklezjologia fundamentalna posługuje się w swoisty sposób ukierunkowaniem historyczno-empirycznym i uwypukla „strukturalną ciągłość” między misją Jezusa z Nazaretu a Kościołem, podkreślając wolę Jezusa w ustanawianiu królestwa Bożego, do czego jest konieczny lud stanowiący widzialny jego aspekt. Kościół zatem staje się wiarygodny, o ile tkwi w Chrystusie. W swoich znamionach (jeden, święty, powszechny, apostolski, maryjny), które jawią się jako dar i zadanie, jest on wezwany do nieustannej reformy i odnowy ze względu na swą

1 Por. Jan Paweł II, List Apostolski „Novo Millennio Ineunte”(6. 01.2001), [w:] „L'Osservatore Romano"(2001), nr 19-20, s. 10. 
złożoność. Świadectwo ochrzczonych staje się najbardziej przekonującym argumentem na rzecz wiarygodności Kościoła.

Współczesna eklezjologia fundamentalna, ujmująca Kościół jako znak wiarygodności, wychodzi więc od aspektu pośredniczenia w wierze i dlatego zajmuje się najpierw problemem wiary ludu Bożego (credere ecclesiam, Kościołem jako podmiotem wiary), aby następnie wskazać jego miejsce w wierze (credere [in] ecclesiam, czyli Kościół jako przedmiot wiary). Dokonuje się tu także przejście od Jezusa Chrystusa do Jego wspólnoty. W ten sposób przybliża się ujęcie wiarygodności na nowej drodze empirycznej, będącej dzisiaj jej paradygmatem i próbuje się przezwyciężyć obiegowe, a fałszywe hasło: „Chrystus - tak, Kościół nie"2. Wiarygodność zatem wprost wiąże się ze świadectwem życia: im bliżej kościelnej codzienności Duchowi Jezusa, tym wyraźniejsze i pewniejsze Jego prowadzenie. Tożsamość i posłanie Kościoła odsłaniają się w jego obecności, i to nie tylko wtedy, kiedy naucza, lecz o wiele bardziej, gdy żyje tym, czego naucza. Przepowiadanie i świadectwo tłumaczą zatem dar i odpowiedzialność Kościoła w konfrontacji ze światem ${ }^{3}$.

Jednakże zarówno przepowiadanie i świadectwo Kościoła stają się nieautentyczne w oczach świata, gdy z całą wyrazistością ujawniają się głębokie nieprawomocne podziały w łonie wspólnoty kościelnej. Należy skonstatować smutny fakt, iż postronny obserwator ma dziś do czynienia z rozbiciem Kościoła Chrystusowego. Ten brak zewnętrznej jedności jest tym bardziej godny pożałowania, iż wiele wspólnot rości sobie pretensje do bycia jedynym autentycznym, odmawiając naturalnie innym tego prawa. Gdzie jest zatem ten jeden prawdziwy? A może święta tajemnica jedności Kościoła sprowadza się jedynie do jego jedności wewnętrznej (ontycznej)? Jeśli tak, to razem z apostołem Pawłem wolno zapytać o podzielenie samego Chrystusa (por. 1 Kor 1, 13).

Z kolei bogactwo Objawienia, choć przyjmuje jeden Kościół Chrystusa, być może dopuszcza różnorodność kościelnych wyznań, aby wzmacniać wewnętrzną jedność ze Zbawicielem? Może istnieje uprawomocniony podział, który w pojednanej różnorodności zakłada jedność w wielości? Cała ta złożona problematyka,

2 Por. G. Horst, Gott ja, Kirche nein. Antworten auf 66x Kritik, Aachen 1997, t. 1, s. 121-178; M. Rusecki, Dlaczego niektórzy akceptuja Chrystusa, a odrzucaja Kościót?, [w:] tenże (red.), Problemy wspótczesnego Kościota, Lublin, 1996, s. 107-116; zob. Ł. Kamykowski, Dlaczego Chrystus? Dlaczego Kościót?, Kraków 1992; zob. S. Pié-Ninot, Introduzione all'Ecclesiologia, Casale Monferrato 1994; zob. H. Blüml, Ja zur Kirche. Eine Streitschrift wider die modischen Vorwürfe gegen die katholische Kirche, Regensburg 1994.

3 Por. M. Crociata, Teologia fondamentale. La Chiesa, Casale Monferrato 1991, s. 16; H. Seweryniak, Sposoby uzasadniania wiarygodności Kościota w nowszej literaturze teologicznej, [w:] T. Dola (red.), Wiarygodność Kościota, Opole 1997, s. 27-48. 
łącznie z kwestią konieczności istnienia Kościoła, będzie stanowić treść teologicznej refleksji pierwszego rozdziału podręcznika.

\section{A. Czy Kościół jest niezbędny?}

Pytanie o potrzebę Kościoła staje się niełatwą kwestią, ogniskującą się w problematyce sensu jego istnienia. Jest to jednocześnie klucz do całej eklezjologii. Każda odpowiedź na pytanie o konieczność jego istnienia będzie zaledwie fragmentaryczna. Opowiadając się ostatecznie pozytywnie za niezbywalnością Kościoła, należy stwierdzić, iż Chrystus planował jego zaistnienie po to, aby służył Jego Duchowi tworzącemu mistyczne ciało Chrystusa. Kościól jest niezbędny ze względu na swoją podstawową funkcję - powszechnego sakramentu zbawienia w świecie i dla świata.

\section{Zasada soteriologiczna}

Człowiek nie jest istotą nieskończoną, ale otwiera się na nieskończoność. Oznacza to, iż w swoich pragnieniach i dążeniach kieruje się nieustannie ku czemuś, co go niezmiernie przerasta. Łaknie wybawienia nie tylko z dręczących go zewnętrznych sytuacji, ale ostatecznie chce być wybawionym od siebie samego. Człowiek dąży do zbawienia. Pozbywając się w końcu wszelkich iluzji, dochodzi on do przekonania, iż źródło jego wybawienia musi znajdować się poza nim samym. Zwraca się więc do Boga, szuka Go, gdyż pragnie nawiązać z Nim kontakt.

Idee zbawienia występują we wszystkich cywilizacjach i ich religiach. Jeśli sięgniemy do myśli greckiej, to w historycznej rekonstrukcji stwierdzimy, iż nadzieja zbawienia była ściśle powiązana z poglądami filozoficznymi dotyczącymi natury i przeznaczenia człowieka. Szczególną rolę odegrały prądy filozoficzno-religijne zainicjowane przez Platona (427-347 przed Chr.), poglądy stoików i neopitagorejczyków. Poszukiwanie zbawienia i różnorodne techniki wyzwalania się człowieka rozbudowano zwłaszcza w tzw. misteriach greckich i hellenistycznych (eleusyńskie, dionizyjskie, ku czci bóstwa słońca Mitry, gnostyckie). W te nurty wpisują się także praktyki buddyjskie zwane „drogą wyzwolenia”. Buddyzm nie ma bogów, wiary i kultu, ale sprowadza się do samowyzwolenia z trojakiego cierpienia (pragnienia rozkoszy, stawania się i przemijania). Te sposoby wyzwalania się nie odwołują się do łaski pochodzącej z zewnątrz, lecz mają się spełnić ludzkim wysiłkiem (autosoteryzm). Całkowicie odmienną ideę zbawienia od występującej w religiach pogańskich proponują religie monoteistyczne (judaizm, chrześcijaństwo i islam), które wyzwolenie człowieka dobitnie przypisują 
jedynie Bogu, negując samozbawienie, chociażby poprzez stosowanie najbardziej wyszukanych metod (rytów wtajemniczenia, wygaszenie pragnień, tajemną wiedzę, ekstatyczne tańce). Szczególną odrębność i wyjątkowość widać zwłaszcza w chrześcijaństwie, głoszącym tajemnicę wcielenia odwiecznego Boga, który jako Mesjasz uwalnia człowieka od grzechów. Jest nim Jezus Chrystus, który nie przestając być Bogiem, stał się człowiekiem.

Chrześcijańską teologię zbawienia w całym jej bogactwie i wieloaspektowości odnajdujemy w Piśmie Świętym, które wprowadza w zupełnie nowy świat myśli, obrazów i symboli. Biblijna teologia zbawienia ukazuje chrześcijaństwo jako religię soteryjną. Po pierwsze głosi ona, że inicjatorem zbawienia jest Bóg, który pochylając się z miłości nad nędzą, nieszczęściem i grzechem człowieka, interweniuje w historię i zbawia. Bóg zbawił ludzkość i świat przez śmierć i zmartwychwstanie swojego Syna, Jezusa Chrystusa. To zatem Bóg jako pierwszy w nadmiarze swej miłości wyszedł ku człowiekowi, uniżył się i ofiarował mu zbawienie, które polega nie tylko na wyzwoleniu z grzechu, ale też na obdarowaniu szczególnymi dobrami. Odkupienie to dar, niczym przez człowieka niezasłużony. Religie pozabiblijne utrzymywały, iż Bóg wyzwala człowieka z materii (ciała) lub historycznie złego świata, zaś objawienie chrześcijańskie mówi o wyzwoleniu ze zła moralnego, z grzechu, co wprowadza drugi aspekt jego soteryjności: człowiek dostępuje zbawienia nie przez negację swojej materialności czy ucieczkę od świata, lecz poprzez zwrot ku Synowi Bożemu, który wszedł w konkretne miejsce i czas świata. Stąd odkupieńcze dobra są przez Boga umieszczone w ludzkiej historii.

Ponadto odkupienie obejmuje całego człowieka, tak w wymiarze biologicznym, psychicznym, jak i duchowym. Powszechne i pełne zbawienie nastąpi dopiero w momencie powszechnego zmartwychwstania (por. 1 Kor 15, 54), gdy powtórnie przyjdzie chwalebny Chrystus (paruzja) jako pierwszy zmartwychwstały spośród tych, co pomarli. Zbawienie zatem rozciąga się na doświadczenie jednostkowe oraz wspólnotowe, obejmuje człowieka i kosmos. Biblia wyklucza indywidualistyczne rozumienie zbawienia, bo choć człowiek zbawia się jako osoba, czyni to jednak we wspólnocie ludu Bożego ${ }^{4}$.

\section{Jezus Chrystus - Prasakrament, Kościół - sakrament podstawowy}

Jezus Chrystus w swojej osobie i dziele jest odczytywany właściwie dopiero wówczas, gdy widzi się Go jako całkowitą i pełną realizację powszechnej woli zbawczej Boga. Ponieważ Bóg jest Stwórcą wszystkich ludzi, dlatego pragnie ich

${ }^{4}$ Por. J. Kudasiewicz, Chrześcijaństwo religiq zbawienia, [w:] M. Rusecki (red.), Byćchrześcijaninem dzis, Lublin 1992, s. 190-212. 
zbawienia. Te zbawcze moce, wysłużone męką, śmiercią i zmartwychwstaniem Jezusa, pozostawił On w gestii wspólnoty wierzących, uznających Jego Syna za Mesjasza. Eklezjologia odnajduje się w chrystologii. Wspólnota, którą gromadzi Duch Jezusa, jest znakiem i narzędziem zbawienia dla swoich członków, ale też dla całego świata. Ukonkretnione i uhistorycznione zbawienie Chrystusa jest zatem udzielane w Jego Kościele i przez Jego Kościół, którego wielowątkowe dzieje sięgają swymi korzeniami nie tyle historii Izraela jako narodu wybranego czy też ofiary pierwszego sprawiedliwego Abla, lecz stworzenia świata i komunii pierwszych ludzi z Bogiem. On bowiem zawsze pragnął, aby wszyscy ludzie jako Jego dzieci - doszli do pełnego poznania i mieli udział w Boskiej naturze, czyli posiadali życie Boże oznaczające więcej niż wieczność.

Eklezjologia pragnie wykazać, iż Kościól jest właściwym przedłużeniem intencji i dzieła Jezusa z Nazaretu, który powołał go do istnienia. W tym celu wypracowała ona podczas II Soboru Watykańskiego (1962-1965) kategorię Kościoła jako sakramentu, wyrażającą z jednej strony jego instrumentalność, czyli misję przekazywania Bożego zbawienia, a z drugiej instytucjonalność i duchowość. Ta kategoria prezentuje podwójną wartość: wewnętrzną (Kościół staje się początkiem sakramentów) oraz zewnętrzną (Kościół pośredniczy w misji zbawienia świata). Oba aspekty są wyraźnie potwierdzone przez Sobór Watykański II, który określa teandryczną naturę wspólnoty eklezjalnej5:

Jest on bowiem ludzki i jednocześnie boski, widzialny i wyposażony w dobra niewidzialne, żarliwy w działaniu i oddany kontemplacji, obecny w świecie, a jednak pielgrzymujący. Wszystkie te właściwości posiada w taki mianowicie sposób, że to, co ludzkie, jest podporządkowane Bożemu i skierowane do Bożego, widzialne do niewidzialnego, życie czynne do kontemplacji, a to, co doczesne - do miasta przyszłego, którego szukamy ${ }^{6}$.

$\mathrm{Z}$ tajemnicy wcielenia wypływają dwie natury zawarte w jednej osobie Jezusa jako Boga i Człowieka. Od chwili inkarnacji staje się On prasakramentem, w którym ludzie mają przystęp do Ojca Niebieskiego, a ich Stwórca staje się jednym z nich. Bóg przyjmuje w swoim odwiecznym Synu ludzką naturę, aby wywyższyć rodzaj ludzki do boskiego poziomu, wskutek czego stajemy się Jego adoptowanymi dziećmi. Posługując się tą analogią, wolno ujmować Kościół jako sakrament podstawowy o złożonej strukturze duchowo-materialnej. Oba elementy nie

\footnotetext{
${ }^{5}$ Por. S. Pié-Ninot, Kościót jako ostatni etap bistorii zbawienia, [w:] M. Rusecki i inni (red.), Chrześcijaństwo Jutra. Materiaty II Międzynarodowego Kongresu Teologii Fundamentalnej. Lublin, 18-21 września 2001, Lublin 2001, s. 411; M. Crociata, Teologia fondamentale. La Chiesa, s. 21-28.

$6 \mathrm{KL} 2$.
} 
mogą istnieć samodzielnie, gdyż wtedy Kościół zatraciłby swoją naturę. Właśnie tutaj najwyraźniej rysuje się podstawowa funkcja Kościoła jako powszechnego sakramentu zbawienia ${ }^{7}$ :

Wyposażona zaś w organa hierarchiczne społeczność i zarazem mistyczne Ciało Chrystusa, widzialne zrzeszenie i wspólnota duchowa. Kościół ziemski i Kościół - bogaty w dary niebiańskie - nie mogą być pojmowane jako dwie rzeczy odrębne, przeciwnie, tworzą one jedną rzeczywistość złożoną, która zrasta się z pierwiastka boskiego i ludzkiego. Dlatego też na zasadzie bliskiej analogii upodabnia się ona do tajemnicy Słowa Wcielonego. Jak bowiem przybrana natura ludzka służy Słowu Bożemu za żywe narzędzie zbawienia, nierozerwalnie z Nim zjednoczone, nie inaczej też społeczny organizm Kościoła służy ożywiającemu go Duchowi Chrystusowemu ku wzrastaniu ciała (por. Ef 4, 16) ${ }^{8}$.

W ten sposób soborowa konstytucja wpisuje Kościół w ciągłość dzieła zbawienia wypełnionego przez Chrystusa, a szczególnie w nawiązaniu do wylania Ducha Świętego - pierwszego daru ofiarowanego wierzącym. W tym sensie można rozumieć Kościół jako sakrament Ducha (jak podają np. W. Kasper, G. Sauter, M. Semerraro, M. Kehl). Jako taki jest on zawsze poza samym sobą, ukierunkowany na Ducha Chrystusa. To Duch Święty jest przyczyną, która sprawia, iż Kościół staje się sakramentem, czyli „sprawia to, co oznacza”, aktualizuje swój podwójny charakter: bycie narzędziem przyczynowo-komunikacyjnym (causat: O. Sammelroth, A. Antón) i bycie znakiem oznaczająco-ujawniającym (significando: K. Rahner, L. M. Chauvet ${ }^{9}$.

\section{B. Jeden Kościół a wielość Kościołów}

Podział chrześcijaństwa na wielkie Kościoły wyznaniowe i na wiele mniejszych osobnych grup kościelnych jest smutnym faktem, wobec którego trudno przejść obojętnie. Wyznawcy Chrystusa, ale i świat znajdują dziś nie tylko jeden

7 Por. F. A. Sullivan, Salvation outside the Church? Tracing the history of the catholic response, London (by Geoffrey Chapman) 1992, s. 141-161; A. Śliwiński, Extra Ecclesiam salus nulla, [w:] EK, t. 4, k. 1474-1475; J. Kracik, „Poza Kościotem nie ma zbawienia”. Historia pojmowania prawdy, „Znak” 44 (1994), nr 5, s. 22-32.

8 KK 8.

9 Por. S. Pié-Ninot, Kościót jako ostatni etap historii zbawienia, [w:] M. Rusecki i inni (red.), Chrześcijaństwo Jutra, dz. cyt., s. 433-435; Cz. Bartnik, Kościót Jezusa Chrystusa, Wrocław 1982; M. Kehl, Die Kirche. Eine katholische Ekklesiologie, Würzburg 1993; tenże, Wohin geht die Kirche? Eine Zeitdiagnose, Freiburg i. Br. 1996. 
Kościól. Żyjemy w sytuacji eklezjalnego pluralizmu. Chrześcijaństwo, obejmujące aktualnie jedną trzecią ludności świata $(2 \mathrm{mld} 300 \mathrm{mln})$, składa się z licznych Kościołów i wspólnot kościelnych. Wśród chrześcijan największą grupę tworzą katolicy (1 mld 300 mln). Według danych z 2019 r. Światowa Rada Kościołów zrzesza 350 wspólnot kościelnych ewangelickich, wschodnich i prawosławnych oraz anglikańskich i innych ${ }^{10}$. Ta wielość stanowi potężne wyzwanie dla ruchu ekumenicznego. Była już ona rozpoznawana w Nowym Testamencie, gdzie przecież jedno, niezmienne apostolskie dziedzictwo wyrażało się w wielości form doktrynalnych i liturgicznych. Ta wielość wynikła z różnorodnych kulturowych i politycznych uwarunkowań świata, z których Duch Pański powoływał człowieka do wspólnoty, a równocześnie posyłał uczniów Chrystusa do różnych zakątków świata. Chrześcijaństwo jest najbardziej rozproszoną religią na globie ziemskim. Stąd istnieją dzisiaj różnorakie sposoby przepowiadania Ewangelii i przedstawiania jej tajemnic. Nie dziwią odmienne formy wyrażania kościelnej dyscypliny, prawd dogmatycznych, udzielania sakramentów i spełniania liturgicznych czynności. Z tego powodu pojawiły się różne Kościoły partykularne, które choć niejednakowo, to wyrażają jedną Owczarnię Chrystusa. Przy tej wielości idzie jednak o taką różnorodność, która wyrasta z podwójnego ruchu: Kościołów partykularnych ku sobie i ku Kościołowi powszechnemu. Albowiem to we wspólnotach partykularnych istnieje i z nich się składa jeden, jedyny Kościół katolicki ${ }^{11}$.

Dlatego jedność należy postrzegać jako uprawomocniony związek różnorodności. Napięcie między jednością a różnorodnością należy także zachować w kontekście eklezjologicznym. O jedności bowiem może być mowa jedynie wówczas, gdy nie traci się z pola widzenia różnorodności. Unifikacja i różnorodność stoją przez to wobec siebie w pozytywnej relacji: tworzą dwa pola jedności.

Jednakże obok tego uprawomocnionego pluralizmu eklezjalnego istnieje wielość nieprawomocna, niszcząca kościelną jedność i katolickość, wynikająca z pragnienia władzy i dominacji jednych nad drugimi. Nieprawomocny pluralizm Kościołów powstaje wówczas, gdy teologiczne i kościelne myślenie traci z oczu posłanie Kościoła w całości Ewangelii oraz nie rozpoznaje szerokości i wielkości orędzia w jego sile asymilacji i integracji, oraz w sytuacji rozwoju życia Kościołów partykularnych w organizacyjnych i konkretnych przejawach w całkowitej izolacji1 ${ }^{12}$.

10 Por. A. Napiórkowski, Teologia jedności chrześcijan, Kraków 2011, s. 36-43. Warto dodać, iż Kościół rzymskokatolicki nie jest członkiem Światowej Rady Kościołów, lecz współpracuje z nią na różnych płaszczyznach.

11 Por. KK 23; J.-M. Tillard, Eglise d'eglises, Paris 1987; tenże, L'Eglise locale, Paris 1995.

12 Por. H. Döring, Grundriss der Ekklesiologie. Zentrale Aspekte des katholischen Selbstverständnis und ibre ökumenische Relevanz, Darmstadt 1986, s. 185-189. 
W sakramentalnym rozumieniu Kościoła jako znaku i narzędzia - z pozycji rzymskokatolickiej - jest on widziany jako kontynuacja inkarnacji. Jednakże to rozumienie nie jest wolne od krytyki czy też różnych podejść do takiej wizji. Kościół jest widziany per analogiam jako wcielenie, co ujawnia się w widzialnych strukturach działającego Ducha Chrystusa ${ }^{13}$. Tak więc communio eklezjalne jest ostatecznie ugruntowane w komunii trynitarnej. Kościół jest - jak wyraża się św. Cyprian - ludem połączonym jednością Ojca, Syna i Ducha Świętego. Źródłem jedności Kościoła jest Przenajświętsza Trójca, stanowiąca jej przyczynę wzorczą, a zarazem sprawczą. Oznacza to, że jedność kościelna podobna jest do jedności trynitarnej, gdyż kształtuje ją Trójca Święta. Dokonuje tego Bóg Ojciec przez odwieczny plan zbawienia wraz z Chrystusem, Wcielonym Synem Bożym, który go urzeczywistnia razem z Duchem Świętym jako zasadą i współrealizatorem tego dzieła w Kościele. Jako communio obejmujące wszystkie ludy, rasy, klasy i pokolenia jest Kościól jednym ludem mesjańskim, widzialnym sakramentem jedności ludzkości ${ }^{14}$. W tej pełnej napięcia, ale niezbywalnej jedności jawi się jako instytucja i wydarzenie, struktura i życie, prawo i duch, grzech i świętość. Stanowi on dziejową i społeczną konkretyzację chrześcijaństwa ${ }^{15}$.

Istota Kościoła wyraża się w jego istotowych przymiotach, wymienionych w wyznaniu wiary Soboru Konstantynopolitańskiego z 381 roku. Kościół jest jeden, święty, katolicki i apostolski. Cechy te są równocześnie znakami jego prawdziwości (notae ecclesiae). $Z$ ich pomocą nie można wprawdzie nikomu go zademonstrować, ale wynika z nich całościowa budowla, która przez swoją spoistość i sensowność posiada siłę przekonywania. Jedność Kościoła to istotny element (przymiot) niewidzialnej i widzialnej struktury, polegający na wewnętrznej jednolitości jego zasadniczych składników. Razem z pozostałymi trzema znakami jedność stanowi kryterium prawdziwości Kościoła i wiąże się istotowo z jego jedynością, czyli niepowtarzalnością jako Chrystusowej wspólnoty zbawienia ${ }^{16}$.

Podział jednego Kościoła na wiele różnych konfesji, który uwidocznił się szczególnie w 1054 r. w oddzieleniu się Rzymu od Bizancjum oraz w reformacyjnych ruchach w XV i XVI w., jest dziejową tragedią, zgorszeniem i skutkiem ludzkiej winy. Wysiłki na rzecz przywrócenia zniszczonej jedności w jej widzialnym wymiarze są zatem próbami sprostania jednemu z większych wyzwań dla podzielonych Kościołów i wspólnot kościelnych. Przez długi czas Kościół

\footnotetext{
13 Por. KK 8.

14 Por. KK 9.

15 Por. W. Kasper, Kirche (Systematisch-theologisch), [w:] Lexikon für Theologie und Kirche, t. 2, Freiburg-Basel-Rom-Wien 1996, k. 1466; por. A. Napiórkowski, Teologia jedności chrzescijan, s. 111-119.

16 Por. S. Nagy, Jedność Kościota, [w:] EK, t. 7, k. 1143.
} 
rzymskokatolicki podnosił w ekskluzywny sposób roszczenie do bycia tym prawdziwym i jedynym. Także po II Soborze Watykańskim zachowuje to mniemanie, albowiem jedynie w nim istnieje pełnia zbawczych środków ${ }^{17}$. Niemniej jednak pozytywnie oceniono eklezjalność Kościołów i wspólnot kościelnych odłączonych od Stolicy Rzymskiej. Zarzucono wreszcie upraszczające koncepcje herezji lub schizmy, ponieważ w innych wspólnotach chrześcijańskich dostrzeżono wartości nieobce katolicyzmowi, choć niekiedy zachowane jedynie w stanie szczątkowym. Podjęto wielkie dzieło ekumenicznego zbliżenia ${ }^{18}$.

Sobór, akcentując wymiary trynitarny, mistyczny i sakramentalny struktury Kościoła, przeszedł od ekskluzywizmu do inkluzywizmu, co wyraziło się odejściem od ścisłego utożsamiania prawdziwego Kościoła Jezusa Chrystusa ze wspólnotą katolicką poprzez rezygnację z atrybutu „rzymski”. Vaticanum II naucza, iż prawdziwy Kościół Chrystusowy trwa (subsistit) w Kościele katolickim, rządzonym przez następcę Piotra oraz biskupów pozostających z nim we wspólnocie (communio)"19. Dla właściwego rozumienia terminu „trwa” (subsistit) należy uwzględnić całość kontekstu. Widać tu wyraźnie, że ta wypowiedź odnosi się do sakramentalno-instytucjonalnego wymiaru Kościoła, a nie do egzystencjalnego wymiaru przeżywanej wiary ${ }^{20}$. Soborowi idzie o instytucjonalny konkret i możliwość identyfikacji jednego i prawdziwego Kościoła poprzez wskazanie na dwa centralne kryteria funkcjonujące od czasów poapostolskich, tj. ciągłość apostolskiej tradycji i powszechną jedność, wyrażające się w sukcesji apostolskiej i, w szczególny sposób, w jedności biskupiego kolegium ze swoim centrum - urzędem Piotrowym. Jednakże ten sam Sobór jednoznacznie oświadczył, że poza organizmem Kościoła katolickiego „znajdują się liczne pierwiastki uświęcenia i prawdy, które jako właściwe dary Kościoła Chrystusowego nakłaniają do jedności katolickiej”21. Do tych elementów zaliczamy zwłaszcza Słowo Boże, chrzest, Ducha Bożego i jego dary, a w Kościołach prawosławnych także Eucharystię i urząd biskupi ${ }^{22}$.

Jakkolwiek Kościół katolicki został ubogacony wszelką prawdą objawioną i wszelkimi środkami łaski, to jednak katolicy muszą „z radością uznać i ocenić dobra naprawdę chrześcijańskie płynące ze wspólnej ojcowizny, które znajdują się u braci od nas odłączonych”. Trzeba też pamiętać, że „cokolwiek sprawia łaska

17 Por. DE 3.

18 Por. DE 14; por. P. Tihon, Kościót, [w:] B. Sesboüé (red.), Historia dogmatów. Znaki zbawienia, t. 2, Kraków 2001, s. 470.

19 KK 8; por. A. Napiórkowski, Teologia jedności chrześcijan, s. 128-136.

${ }^{20}$ Por. M. Kehl, Die Kirche, dz. cyt., s. 415-422.

${ }^{21}$ KK 8.

${ }^{22}$ Por. W. Kasper, Kirche (Systematisch-theologisch), art. cyt., k. 1468-1469; J. Morawa, Sukcesja apostolska, [w:] LTF, s. 1141-1147. 
Ducha Świętego w odłączonych braciach, może również nam posłużyć ku zbudowaniu"23. Kościoły i wspólnoty chrześcijańskie współposiadają doniosłe pierwiastki kościelnej jedności, które powodują, że one same - pozostając w niepełnej wspólnocie z Kościołem katolickim - dążą do przełamywania przeszkód utrudniających pełną komunię. W Kościołach i wspólnotach oderwanych od wspólnoty katolickiej, na gruncie posiadanych przez nie „dóbr Kościoła” oraz działających w nich „środków zbawienia”, istnieje wystarczająca eklezjalność, aby były one dla swoich członków narzędziami zbawienia. Najboleśniejszym skutkiem rozbicia Kościoła Chrystusowego pozostaje brak wspólnoty Eucharystii, która jest przecież sakramentem jedności. Ta sytuacja „utrudnia samemu Kościołowi w konkretnym życiu uwypuklenie pełni katolickości pod każdym względem"24. Stąd chrześcijanie, nie będąc ze sobą zjednoczeni, nie są wobec świata w pełni świadkami Jezusa. Modląc się za przyszły Kościól, nasz Pan błagał Ojca Niebieskiego:

Nie tylko za nimi proszę, ale i za tymi, którzy dzięki ich słowu będą wierzyć we Mnie; aby wszyscy stanowili jedno, jak Ty, Ojcze, we Mnie, a Ja w Tobie, aby i oni stanowili w Nas jedno, aby świat uwierzył, żeś Ty Mnie posłał (J 17, 20-21).

${ }^{23}$ DE 4; por. F. A. Sullivan, Salvation outside the Church?, dz. cyt., s. 182-198.

${ }^{24}$ DE 4; por. S. Nagy, Jedność Kościota (doktryna Kościoła katolickiego), [w:] EK, t. 7, k. 11441148; A. Napiórkowski, Jedność konsekrowana, Kraków 2002, s. 161-173. 